\author{
DEPARTMENT OF THE INTERIOR \\ UNITED STATES GEOLOGICAL SURVEY
}

PREPARED IN COOPERATION WITH THE

MICHIGAN DEPARTMENT OF NATURAL RESOURCES

GEOLOGICAL SURVEY DIVISION

\title{
AEROMAGNETIC MAP OF THE WESTERN PART OF THE NORTHERN PENINSULA, MICHIGAN AND PART OF NORTHERN WISCONSIN
}

\author{
By
}

Isidore Zietz and John R. Kirby

\author{
GEOPHYSICAL INVESTIGATIONS \\ MAP GP-750
}

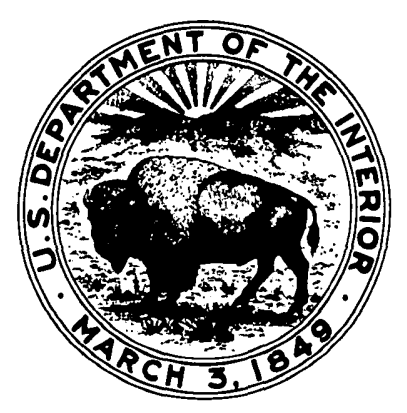

PUBLISHED BY THE U. S. GEOLOGICAL SURVEY 